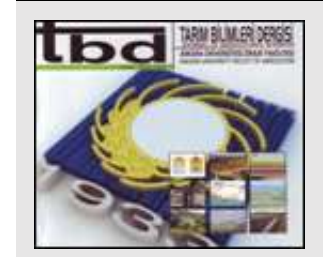

Tarım Bilimleri Dergisi Tar. Bil. Der.

Dergi web sayfasi: www.agri.ankara.edu.tr/dergi
Journal of Agricultural Sciences

Journal homepage:

www.agri.ankara.edu.tr/journal

\title{
Physiological Responses of Gamma-Irradiated Onion Bulbs during Storage
}

\author{
Sahel MILADI LARI ${ }^{\mathrm{a}}$, Mehrdad AHMADI*b ${ }^{*}$, Abdolkarim KASHI ${ }^{\mathrm{c}}$, Amir MOUSAVId ${ }^{\mathrm{d}}$, Younes MOSTOFI ${ }^{\mathrm{c}}$ \\ ${ }^{a}$ Department of Horticultural Science and Agronomy, Science and Research Branch, Islamic Azad University, Tehran, IRAN

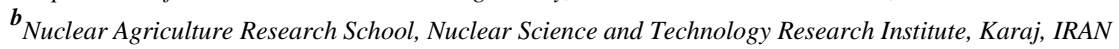 \\ ${ }^{c}$ Department of Horticultural Science, College of Agriculture, University of Tehran, Karaj, IRAN

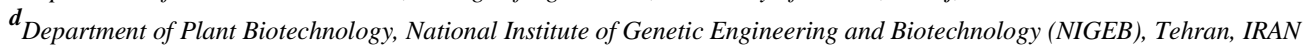

\author{
ARTICLE INFO \\ Research Article \\ Corresponding Author: Mehrdad AHMADI, E-mail: mdaahmadi@aeoi.org.ir, Tel: +98 (261) 2614411102 \\ Received: 01 May 2019, Received in Revised Form: 19 August 2019, Accepted: 25 August 2019
}

\section{AUTHORS ORCID ID:}

(Sahel MILADI LARI: 0000-0001-5373-9851), (Mehrdad AHMADI: 0000-0001-7226-8397), (Abdolkarim KASHI: 0000-0002-6198-4918 ), (Amir MOUSAVI: 0000-0003-0067-4294 ), (Younes MOSTOFI: 0000-0003-3975-1429)

\section{ABSTRACT}

The present study aimed to evaluate the effects of different doses of gamma radiation on some physiological characters of onion genotypes and the expression of $P A L$ gene in the best interaction of gamma irradiation dose and onion genotype treatment. To this aim, four onion genotypes (White-Qom, White-Neyshabour, Red-RidgeLump, and Red-Ray-Corrugated) irradiated at 0, 30, 60, 90, 120, and $150 \mathrm{~Gy}$. After four months of storage (at $10-15{ }^{\circ} \mathrm{C}$ and $70 \%$ relative humidity), the effects of gamma rays on the dry matter (DM), protein content, phenylalanine ammonia lyase (PAL) and peroxidase (POD) were investigated. In addition, the expression of $P A L$ gene in the best interaction of gamma irradiation dose and onion genotype treatment was assessed. The result indicated that
POD activity was increased by most of the gamma irradiation levels; however, the protein content and PAL activity were decreased. Moreover, dry matter content was found to be highly genotype-dependent. A linear regression $\left(\mathrm{R}^{2}=0.82\right)$ between PAL activity and gamma irradiation levels, was observed. PAL activity decreased with increasing in gamma irradiation level, while the expression rate of $P A L$ gene was not significantly changed between irradiated and non-irradiated control, indicating that the radiation might not have direct effects on the gene regulatory elements. These results suggest that gamma irradiation could reduce the PAL activity possibly by controlling abiotic stress sources such as fungal and bacterial stresses.

Keywords: Gamma radiation; Allium cepa; PAL activity; Gene expression

(C) Ankara Üniversitesi Ziraat Fakültesi

\section{Introduction}

Onion (Allium cepa L.) is one of the most important vegetable crops, a member of the Liliaceae family (Sabiu et al 2019). Onion is commonly used for its flavor, nutritional and medicinal values. Jones \& Mann (1964) proposed that Pakistan and Iran are the onion primary center of origin. Since ancient times, it is highly consumed in Iran (Fakhri et al 2018). Iran with $2,379,000$ tons annually onion production, was among the top four producer countries (FAO 2017).

Biochemical changes in the onion bulb tissues exposed to different adverse environmental conditions caused a reduction in their quality (Benkeblia et al 2003; Benkeblia et al 2004). Gamma irradiation have been widely used as a safe and effective method to increase storage time and shelf life in some crops such as onion (Nouri \& Toofanian 2001), potato (Frazier et al 2006), pistachio (Akbari et al 2018), peach (Khan et al 2018), and pomegranate (Ashtari et al 2019). 
The effect of gamma irradiation on storage life is due to control of fungal and bacterial infections (Pereira et al 2015; Fernandes et al 2016) and delay in ripening and growth inhibition (Kader 1986). Also, studies have shown that the gamma irradiation can affect physiological, chemical, biological changes in the crops (Di Stefano et al 2014; Pereira et al 2016).

Dry matter is one of the most important quality criteria in onion. Studies showed that gamma irradiation had a positive effect on onion dry matter resulted in increasing the storage life (Rutherford \& Whittle 1984). Non-structural carbohydrates are the main compound of dry matter (Darbyshire \& Henry 1981). Ionized bulbs can increase the storage life for several months, whereas it can affect the carbohydrates content (Benkeblia et al 2004). When the crops tissues damaged by cutting, grinding or pulping, phenolic compounds produce by phenylalanine ammonia lyase (PAL), then they oxidized by polyphenol oxidase (PPO) and peroxidase (POD) which polymerize to brown pigments (Mai \& Glomb 2013).

PAL is a key enzyme in the phenyl propanoid biosynthesis pathway, which catalyzes the elimination of ammonia from L-phenylalanine to give trans-cinnamate, which is the first step in the biosynthesis of plant-specific phenylpropanoid derivatives such as phenolic compounds (Benkeblia 2000; Hamamouch \& Adil 2019). PAL activity was found to vary in different plant development stage and various stresses ( $\mathrm{Li}$ et al 2017). The main role of POD is to oxidize molecules at the expense of $\mathrm{H}_{2} \mathrm{O}_{2}$. It is possibly involved in the dormancy of onion bulbs and inverse relationships have been reported between the growth rate and POD activity (Benkeblia 2000).

Despite the fact that there are many reports on the application of gamma irradiation on the onion commercial quality traits, however, the effect of gamma irradiation on PAL, POD and protein content has not been investigated. While the germicidal impact of gamma irradiation in more than 70 crops and in many countries has been widely studied for disinfection (Steele 2000; Jeong et al 2016; Jeong et al 2017; Wang et al 2019). The present study aimed to evaluate: 1) the effects of different doses of gamma radiation on POD, protein content, dry matter and phenylalanine ammonia lyase (PAL) during storage life of four onion genotypes, and 2) the expression of $P A L$ gene in the best interaction of gamma irradiation dose and onion genotype treatment.

\section{Material and Methods}

\subsection{Experimental conditions}

In the current study, four onion genotypes (White-Ghom, White-Neyshabour, Red-Ridge-Lump, and Red-RayCorrugated), were subjected to gamma irradiation at Karaj Nuclear Agriculture Research Center in 2016. A factorial experiment was performed based on a completely randomized design with three replications and two factors. The factors included four onion genotypes and six irradiation intensity $(0,30,60,90,120$, and 150 Gy), from a Cobalt-60 gamma resource (with a dose rate of 0.3 gray/second and specific activity of 2300 curie). The onion bulbs were packed in mesh bag after irradiation and stored for four months at $10-15{ }^{\circ} \mathrm{C}$ and $70 \%$ relative humidity. After the onion bulbs storage period, the following characters were recorded POD activity $\left(\mathrm{U} \mathrm{g}^{-1}\right)$, protein content $\left(\mathrm{mg} \mathrm{g}^{-1}\right)$, dry matter $(\%)$ and PAL activity $\left(\mathrm{U} \mathrm{g}^{-1}\right)$.

\subsection{Peroxidase assay}

$100 \mathrm{mg}$ of onion tissues were homogenized with $20 \mathrm{~mL}$ sodium phosphate buffer $(\mathrm{pH}$ 6.8) and grounded by a cold pestle and mortar. The homogenates were transferred into $2 \mathrm{~mL}$ Eppendorf tube and then centrifuged at $12000 \mathrm{rpm}$ for $20 \mathrm{~min}$ at $4{ }^{\circ} \mathrm{C}$. POD activity measured in a reaction mixture including $100 \mu \mathrm{L}$ enzyme extract, $10 \mu \mathrm{L} \mathrm{H}_{2} \mathrm{O}_{2} 30 \%(\mathrm{w} \mathrm{v}$ ${ }^{1}$ ), $200 \mathrm{~mL}$ Guaiacol and $20 \mathrm{~mL}$ phosphate buffer (pH 6) (MacAdam et al 1992). Absorbance was measured at $470 \mathrm{~nm}$ for $60 \mathrm{sec}$ (15-sec interval) using a UV-VIS spectrophotometer.

\subsection{Protein content}

The bulb tissues $(600 \mathrm{mg}$ ) were homogenized with $4 \mathrm{~mL}$ of sodium phosphate buffer (pH 6.8) and centrifuged for 10 min at $15000 \mathrm{rpm}$ in $4{ }^{\circ} \mathrm{C}$. The supernatant was transferred to a new cold $2 \mathrm{~mL}$ tube until assessment. Protein content was measured according to the Bradford method using bovine serum albumin (BSA) as a standard (Bradford 1976).

Journal of Agricultural Sciences (Tarım Bilimleri Dergisi) 26 (2020) 442-451 


\subsection{Phenylalanine ammonia lyase}

The PAL was determined according to Cheng \& Breen (1991) method. Onion bulbs tissue (10 g) were homogenized in $100 \mathrm{~mL}$ acetone and then extracted at $4^{\circ} \mathrm{C}$ with $50 \mathrm{~mL}$ of extraction buffer. The extraction buffer was included $38 \mathrm{~g} \mathrm{~L}^{-1}$ sodium borate ( $\mathrm{pH} 8.8$ ), $0.39 \mathrm{~g} \mathrm{~L}^{-1}$ beta-mercaptoethanol, $0.58 \mathrm{~g} \mathrm{~L}^{-1} \mathrm{EDTA}$, and PVPP at $\mathrm{g} / 100 \mathrm{~g}$ of fresh weight. After $1 \mathrm{~h}$ of extraction, the solution was filtered and centrifuged at $20000 \times \mathrm{g}$ and kept in $4{ }^{\circ} \mathrm{C}$ for $15 \mathrm{~min}$. After $10 \mathrm{~min}$ of preincubation, sodium borate buffer $(1.5 \mathrm{~mL} ; \mathrm{pH} 8.8)$ and L-phenylalanine $(1 \mathrm{~mL})$, were added to $0.5 \mathrm{~mL}$ of supernatant. Finally, PAL was measured at $290 \mathrm{~nm}$ wavelength by spectrophotometer.

\subsection{Dry matter content}

The samples were oven-dried at $75^{\circ} \mathrm{C}$ for $24 \mathrm{~h}$. The dry matter content was determined using the following formula:

$$
\text { Dry matter }(\%)=\frac{\text { Dry weight }}{\text { Initial weight }} \times 100
$$

\subsection{RNA extraction and $q R T-P C R$}

Total RNA was extracted from bulb tissues using the RNeasy Plant Mini kit QIAGEN according to the manufacturer's instructions. Genomic DNA removed by treatment with DNase I during the RNA extraction. The quality and quantity of RNA samples were measured by a NanoDrop spectrophotometer and an absorption ratio (A260/A280) of $\geq 1.9$ were used for reverse transcription. cDNA synthesis was performed by $2 \mu \mathrm{g}$ of total RNA using RevertAid First Strand cDNA Synthesis kit (Thermo Scientific, USA). Real-time PCR was performed on the Corbett Rotor-Gene 6000 using Power SYBR green master mix (Life Technologies). The q-PCR conditions were as follows: $95^{\circ} \mathrm{C}$ for 2 min, followed by 42 cycles of $95{ }^{\circ} \mathrm{C}$ for $5 \mathrm{sec} ; 62^{\circ} \mathrm{C}$ for $45 \mathrm{sec}$ followed by a melting curve analysis from $72-95^{\circ} \mathrm{C}$ with two technical and three biological replicates. B-tubulin was used as the internal reference gene. Relative expression of PAL was calculated by Livak method (Livak \& Schmittgen 2001). The used primers are shown in Table 1

Table 1- List of primers used for Real-time PCR analysis

\begin{tabular}{ll}
\hline Gene & Primer \\
\hline B-tubulin- forward & 5'-GGAAGCATGTGCCCGTGCTATATTTG-3' \\
B-tubulin- reverse & 5'-ACAATCTGGATCGTGCGCTTCGTCTTT-3' \\
AcPAL- forward & 5'-TACCCAGCAAAAGAGGTAGC-3' \\
AcPAL- reverse & 5'-CTGGAATGTCTGACACCATC-3' \\
\hline
\end{tabular}

\subsection{Statistical analysis}

The data were analyzed using SAS (Statistical Analysis System) software (SAS Institute, Cary, NC). The means were compared using the least significant difference (LSD) test (Steel \& Torrie 1980). Cluster analysis was performed using the UPGMA method and SPSS 20.0 on Windows (SPSS Inc., Chicago, IL). To find relationships among the measured characters, Pearson correlation coefficient, was used. The correlation analysis was shown as a heat map using MetaboAnalyst (Xia \& Wishart 2016).

\section{Results and Discussion}

\subsection{ANOVA and means comparison for the measured characters}

The ANOVA demonstrated that there were significant differences $(\mathrm{P}<0.01)$ among the studied factors including four onion genotypes, six irradiation levels and their interaction for following traits: POD activity, protein content, PAL and dry matter (\%) (Table 2). According to Wickens \& Keppel (2004), when the interaction of two factors is significant, then less attention is paid to the two main effects and we focused on the interaction effect. Therefore, in the present study, we have focused on the interaction of onion genotypes and irradiation levels. The result of mean comparison indicated that POD activity increased by most of gamma irradiation levels. To find a relationship between POD activity and gamma irradiation, the regression analysis, was applied. The result showed a linear regression $\left(\mathrm{R}^{2}=0.73\right)$ between 
POD activity and gamma irradiation (Figure 1). The maximum of POD activity in each genotype was related to different irradiation levels, for example, the maximum of the character in white Qom genotype was obtained at 120 Gy irradiation (20.91 $\mathrm{U} \mathrm{g} \mathrm{g}^{-1}$ ), whereas the maximum of this trait in white Neishabur genotype was founded at $90 \mathrm{~Gy}$ irradiation. POD activity was decreased in all genotypes irradiated at $30 \mathrm{~Gy}$ than the control treatments. One of the important roles of POD is degrading indole acetic acid (IAA) activity, which is involved in the growth and dormancy of onion bulbs (Nissen 1985; Benkeblia 2000). The result showed that gamma irradiation in different levels increased the POD activity in all the onion genotypes, as the POD activity has inverse relationships with the growth rate (Gardiner \& Cleland 1974), therefore the quality and the time of storage of the onion bulbs can be improved by gamma irradiation. POD is an important antioxidant enzyme that plays a role in ROS scavenging. POD activity was increased in Vicia faba and Glycine max after gamma rays applied (20 Gy) (Moussa 2008; Moussa 2011). There are many reports about the improvement of POD activity using radiation in different plants such as Raphanus sativus (Lee et al 2003), Triticum aestivum (Hong et al 2018); Hordeum vulgare (Wang et al 2018) and Phoenix dactylifera (Zarbakhsh \& Rastegar 2019).

Table 1- ANOVA of studied traits in four onion genotypes under gamma irradiation

\begin{tabular}{|c|c|c|c|c|c|}
\hline \multirow{2}{*}{ S.O.V } & \multirow{2}{*}{$D . F$} & \multicolumn{4}{|c|}{ Mean square } \\
\hline & & $P O D$ & Protein & Dry matter & $P A L$ \\
\hline Genotype (A) & 3 & $338.25 * *$ & $22.99 * *$ & $1.39 * *$ & $0.67 * *$ \\
\hline Gamma irradiation (B) & 5 & $414.55 * *$ & $75.79 * *$ & $1.92 * *$ & $1.04 * *$ \\
\hline $\mathrm{A} \times \mathrm{B}$ & 15 & $130.78 * *$ & $15.69 * *$ & $7.19 * *$ & $0.98 * *$ \\
\hline Error & 48 & 0.157 & 0.305 & 0.318 & 0.103 \\
\hline C.V (\%) & - & 5.15 & 5.64 & 5.66 & 17.50 \\
\hline
\end{tabular}

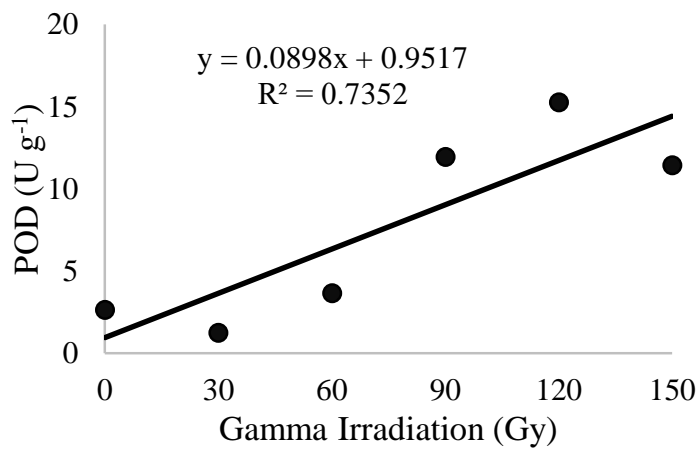

Figure 1- Plot depicting the relation between POD content and gamma irradiation levels in onion

The highest PAL activity in the white-Qom and red-Ray-Corrugated genotypes (3.367 and $2.27 \mathrm{U} \mathrm{g}^{-1}$, respectively) were observed in their control treatments, whereas in white-Neishabur and Red-Ridge-Lump genotypes were observed at 60 and $120 \mathrm{~Gy}$, respectively (Table 3). However, the lowest PAL activity in three genotypes (White-Qom, Red-RayCorrugated, and White-Neishabur) was obtained at $150 \mathrm{~Gy}$, whereas in Red-Ridge-Lump genotype was revealed at 90 Gy. Therefore it can be concluded that PAL activity was depended on onion genotype, under normal and irradiated conditions. PAL is known as a key enzyme in the phenylpropanoid pathway related to phenolic compounds synthesis, which accumulates during different plant stress such as tissue damage, nutrient deficiencies, fungal, bacterial, and insect attack (He \& Luo 2007; Daayf et al 2012). Tripathi \& Variyar (2016) reported that PAL activity remained stable during storage of Benincasa hispida under the application of gamma irradiation. The authors revealed that during the plant storage, as the irradiated samples were protected from spoilage, the PAL activity remained unchanged. PAL and POD induction is a defense mechanism of plant tissues from external stress. The results of this study revealed that gamma irradiation improved the PAL and POD activities in the onion storage, which proposes that these enzymes may be involved in the onion defense mechanism. Figure 2 showed the relation between PAL activity and gamma irradiation in White-Qom genotype. A linear regression $\left(\mathrm{R}^{2}=0.82\right)$ between PAL activity and gamma irradiation levels, was observed. 
Table 2- Mean comparisons of studied traits in onion genotypes under different irradiation levels

\begin{tabular}{|c|c|c|c|c|c|}
\hline Genotype & $\begin{array}{l}\text { GI } \\
(G y)\end{array}$ & $\begin{array}{l}P O D \\
\left(U g^{-1}\right)\end{array}$ & $\begin{array}{l}\text { Protein } \\
\left(m g g^{-1}\right)\end{array}$ & $\begin{array}{l}D M \\
(\%)\end{array}$ & $\begin{array}{l}P A L \\
\left(U g^{-1}\right)\end{array}$ \\
\hline \multirow{6}{*}{ White-Qom } & 0 & 3.153 & 13.93 & 9.803 & 3.367 \\
\hline & 30 & 2.53 & 9.657 & 9.047 & 2.133 \\
\hline & 60 & 4.577 & 10.32 & 10.31 & 2.10 \\
\hline & 90 & 6.583 & 10.13 & 7.577 & 2.157 \\
\hline & 120 & 20.91 & 5.61 & 12.45 & 1.38 \\
\hline & 150 & 9.62 & 6.84 & 11.97 & 1.257 \\
\hline \multirow{6}{*}{ White-Neishabur } & 0 & 4.477 & 13.11 & 10.84 & 1.023 \\
\hline & 30 & 0.727 & 10.33 & 9.657 & 1.66 \\
\hline & 60 & 1.01 & 12.62 & 11.49 & 2.647 \\
\hline & 90 & 19.03 & 9.803 & 9.323 & 2.013 \\
\hline & 120 & 22.84 & 11.05 & 10.57 & 2.123 \\
\hline & 150 & 31.07 & 8.007 & 9.083 & 1.50 \\
\hline \multirow{6}{*}{ Red-Ridge-Lump } & 0 & 1.73 & 11.54 & 9.183 & 1.59 \\
\hline & 30 & 1.383 & 18.09 & 9.123 & 1.633 \\
\hline & 60 & 6.32 & 12.46 & 8.407 & 2.193 \\
\hline & 90 & 19.94 & 8.13 & 10.23 & 1.387 \\
\hline & 120 & 9.43 & 7.35 & 10.21 & 2.213 \\
\hline & 150 & 3.36 & 5.937 & 10.45 & 2.00 \\
\hline \multirow{6}{*}{ Red-Ray-Corrugated } & 0 & 1.187 & 12.12 & 8.623 & 2.267 \\
\hline & 30 & 0.313 & 9.37 & 12.85 & 0.99 \\
\hline & 60 & 2.623 & 10.82 & 9.857 & 1.953 \\
\hline & 90 & 2.177 & 4.00 & 10.19 & 2.067 \\
\hline & 120 & 7.817 & 7.753 & 7.807 & 1.347 \\
\hline & 150 & 1.653 & 6.183 & 9.877 & 0.943 \\
\hline $\operatorname{LSD}(0.01)$ & & 0.87 & 1.21 & 1.23 & 0.70 \\
\hline
\end{tabular}

GI, gamma irradiation; DM, dry matter

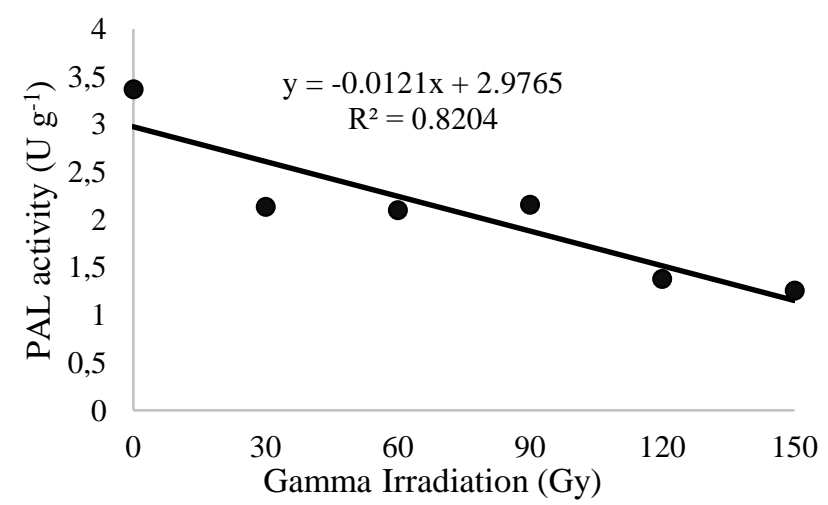

Figure 2- Plot depicting the relation between PAL activity and gamma irradiation levels in white-Qom

The highest protein content in the White-Qom, White-Neishabur and Red-Ray-Corrugated genotypes (13.93, 13.11, and $12.12 \mathrm{mg} \mathrm{g}^{-1}$, respectively) were observed in their control treatments, whereas, the highest value for this character in Red-Ridge- Lump was observed at $30 \mathrm{~Gy}\left(18.09 \mathrm{mg} \mathrm{g}^{-1}\right)$. The result showed that with increasing the gamma irradiation levels, the protein content decreased. To find a relationship between protein content and gamma irradiation, a regression analysis, was used (Figure 3). The result of the regression analysis indicated that there was a linear regression between the onion protein content and gamma irradiation. El-Beltagi et al (2011) reported that with increasing the gamma irradiation doses, the protein synthesis and enzyme activity were disrupted. The results of the present study are in contrast with Ling et al (2008), who found that the citrus samples irradiated at high doses showed higher protein content compared to their control samples. However, in Red-Ridge-Lump genotype at the dose of $30 \mathrm{~Gy}$, the protein content was increased as compared to its control. It seems that the onion genotypes had a different response to gamma irradiation. 


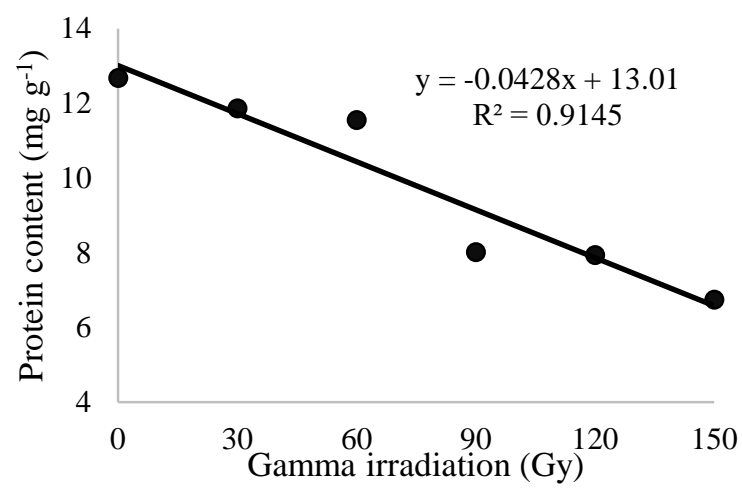

Figure 3- Plot depicting the relation between protein content and gamma irradiation levels in onion

Dry matter is an imperative quality character in onion bulbs, which is supposed to have a relationship with storage time and bulb properties. The results showed that dry matter content was highly genotype-dependent. In the White-Qom genotype, the lowest (7.57\%) and the highest (12.45\%) dry matter were achieved at doses of 90 and 120 Gy, respectively, which had significant differences with control treatment $(9.8 \%)$. The interaction of Red-Ray-Corrugated with a dose of $30 \mathrm{~Gy}$ had the highest dry matter (12.85\%) among the other interaction treatments. Glucose, fructose, and sucrose are the main parts of DM, which are non-structural carbohydrates (Benkeblia et al 2004). These carbohydrates are about $70-80 \%$ of the bulb dry matter (Böttcher et al 2018). The compositions of dry matter have changed during the storage period. Also, during frying, it can change to fructose and glucose that are active in non-enzymatic browning (Clark et al 2018). Onions storage for the long term is one of the problems in the frying industry, resulting in the darker and more bitter the fried product (Asefi \& Mozaffari 2010).

\subsection{Cluster and correlation analyses}

The dendrogram was generated using the following measured parameters, PAL, POD, protein content, and dry matter, which grouped the onion genotypes into two clusters (Figure 4). The first group included G1 (White-Ghom) and G2 (White-Neyshabour) genotypes. This group had the highest values of DM, protein content, and POD activity than the second group, which means that the quality of genotypes in this group were better than the genotypes in the second group. Two other genotypes including G3 (Red-Ridge-Lump) and G4 (Red-Ray-Corrugated) were in the second group. Based on the cluster analysis there was a moderate diversity among the four studied onion genotypes. These variation is due to genetic factors among the samples (Ebrahimi et al 2012; Farajpour et al 2017; Boroomand et al 2018; Hassanabadi et al 2019). Among the parameters, DM and POD activity had the highest positive correlation coefficient with each other $(\mathrm{r}=0.76 ; \mathrm{P}<0.01$; Figure 5$)$. However, the highest negative correlation was between $\mathrm{DM}$ and $\mathrm{PAL}$ activity. Protein and POD had a significant correlation with each other $(r=0.63 ; \mathrm{P}<0.05)$.

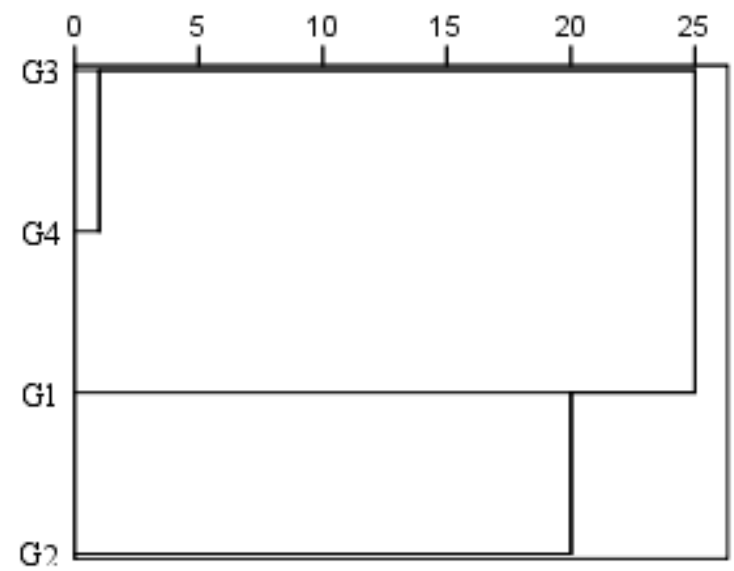

Figure 4- Dendrogram generated based on the four measured characters on the four onion genotypes using UPGMA method 


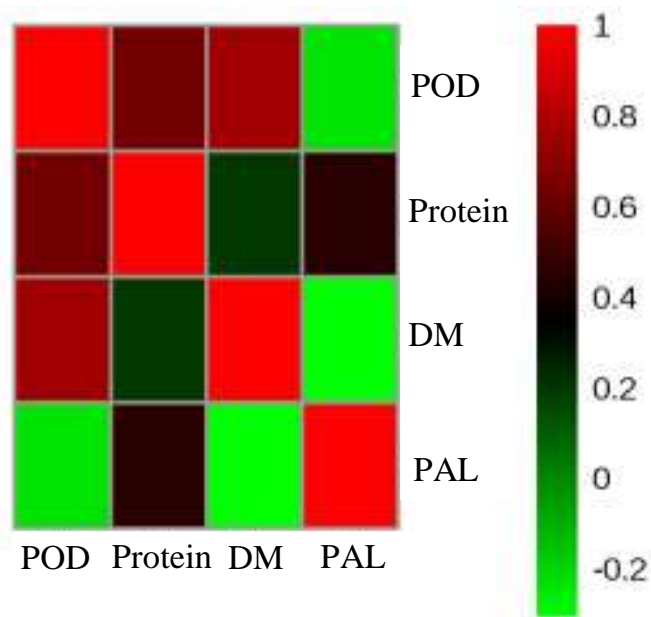

Figure 5- Heat map of the correlations between the four studied characters of the four onion genotypes

\subsection{Real-time PCR analysis of PAL gene}

In order to evaluate the effects of gamma irradiation on the relative expression of $P A L$ gene, quantitative Real-time PCR analysis, was performed. Based on data obtained from PAL activity and sprouting (data not shown), the relative expression of PAL gene in White-Qom genotype at $150 \mathrm{~Gy}$, was assessed. Non-irradiated onion bulbs were used as control. Results showed that there was no significant difference between onion bulbs irradiated by 150 Gy and nonirradiated bulbs in terms of PAL gene expression (Figure 6). Results revealed that the PAL activity decreased at higher gamma irradiation levels, while the expression level of the $P A L$ gene was not significant between irradiated and nonirradiated control bulbs. This may be due to the effects of gamma irradiation in controlling the fungal, bacterial or other sources of stresses in onion bulb, resulting in reduced PAL activity at higher gamma irradiation doses (Calado et al 2014; Jeong et al 2016). Based on the results, the PAL gene expression was not affected by gamma irradiation, indicating that the radiation might not have direct effects on the PAL gene regulatory elements. These results suggest that gamma irradiation could reduce the PAL activity possibly by controlling abiotic stress sources such as fungal and bacterial stresses; it can be pointed out as a positive point, which can reduce food safety concerns.

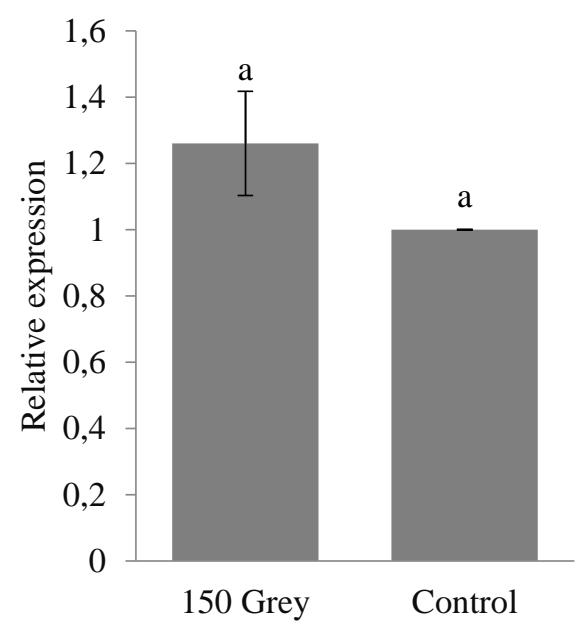

Figure 6- Relative expression of $P A L$ gene in White Qom onion genotype treated by 150 Gy gamma irradiation

\section{Conclusions}

The present study revealed the feasibility of gamma irradiation as an efficient tool for the management of onion storage. The result indicated that POD activity increased by most of the gamma irradiation levels, however, the protein content 
and PAL activity decreased. Also, the result showed that onion genotypes had a different response to gamma irradiation. Among the genotypes, White-Ghom and White-Neyshabour had the highest quality. The PAL activity decreased with increasing in gamma irradiation levels, while the expression level of the PAL gene was not significant between irradiated and non-irradiated control bulbs. Based on literature review, biotic and abiotic stresses increase the PAL activity. So it can be concluded that gamma irradiation caused to control the source of stresses such as fungal and bacterial. Therefore, with increasing the level of gamma irradiation, the PAL activity was decreased, indicating that the gamma radiation did not make any mutation in the $P A L$ gene. So it can be used as a useful method, which can reduce food safety concerns.

\begin{tabular}{|ll|}
\hline \multicolumn{2}{|l|}{ Abbreviations and Symbols } \\
\hline Gy & gray \\
DM & dry matter \\
PAL & phenylalanine ammonia lyase \\
POD & peroxidase \\
BSA & bovine serum albumin \\
LSD & Least Significant Difference \\
ANOVA & analysis of variances \\
\hline
\end{tabular}

\section{References}

Akbari M, Farajpour M, Aalifar M \& Sadat Hosseini M (2018). Gamma irradiation affects the total phenol, anthocyanin and antioxidant properties in three different persian pistachio nuts. Natural Product Research 32(3): 322-326

Asefi N \& Mozaffari M (2010). Effects of drying, packaging, and temperature on the quality of fried onion slices. Journal of Food Science 75(5): S251-S254

Ashtari M, Khademi O, Soufbaf M, Afsharmanesh H \& Sarcheshmeh M A A (2019). Effect of gamma irradiation on antioxidants, microbiological properties and shelf life of pomegranate arils cv.'Malas Saveh'. Scientia Horticulturae 244: 365-371

Benkeblia N (2000). Phenylalanine ammonia-lyase, peroxidase, pyruvic acid and total phenolics variations in onion bulbs during long-term storage. LWT-Food Science and Technology 33(2): 112-116

Benkeblia N, Onodera S \& Shiomi N (2003). Effect of temperature and storage time on fructosyltransferase activities (1-FFT and 6G-FFT) in onion bulb tissues. Acta Agric Scand (B) 53(4): 211-214

Benkeblia N, Onodera S \& Shiomi N (2004). Effect of gamma irradiation and temperature on fructans (fructo-oligosaccharides) of stored onion bulbs Allium cepa L. Food Chemistry 87(3): 377-382

Boroomand N, Sadat-Hosseini M, Moghbeli M \& Farajpour M (2018). Phytochemical components, total phenol and mineral contents and antioxidant activity of six major medicinal plants from Rayen, Iran. Natural Product Research 32(5): 564-567

Böttcher C, Krähmer A, Stürtz M, Widder S \& Schulz H (2018). Effect of cultivar and cultivation year on the metabolite profile of onion bulbs (Allium cepa 1.). Journal of Agricultural and Food Chemistry 66(12): 3229-3238

Bradford M M (1976). A rapid and sensitive method for the quantitation of microgram quantities of protein utilizing the principle of protein-dye binding. Analytical Biochemistry 72(1-2): 248-254

Calado T, Venâncio A \& Abrunhosa L (2014). Irradiation for mold and mycotoxin control: a review. Comprehensive Reviews in Food Science and Food Safety 13(5): 1049-1061

Cheng G W \& Breen P J (1991). Activity of phenylalanine ammonia-lyase (PAL) and concentrations of anthocyanins and phenolics in developing strawberry fruit. Journal of the American Society for Horticultural Science 116(5): 865-869

Clark C J, Shaw M L, Wright K M \& McCallum J A (2018). Quantification of free sugars, fructan, pungency and sweetness indices in onion populations by FT-MIR spectroscopy. Journal of the Science of Food and Agriculture 98(14): 5525-5533

Daayf F, El Hadrami A, El-Bebany A F, Henriquez M A, Yao Z, Derksen H, El Hadrami I \& Adam L R (2012). Phenolic compounds in plant defense and pathogen counter-defense mechanisms. Recent Advances in Polyphenol Research 3(8): 191-208 
Darbyshire B \& Henry R (1981). Differences in fructan content and synthesis in some Allium species. New Phytologist 87(2): 249256

Di Stefano V, Pitonzo R \& Giuseppe A (2014). Effect of gamma irradiation on aflatoxins and ochratoxin A reduction in almond samples. Journal of Food Research 3(4): 113-118

Ebrahimi M, Farajpour M \& Rahimmalek M (2012). Inter-and intra-specific genetic diversity of Iranian yarrow species Achillea santolina and Achillea tenuifolia based on ISSR and RAPD markers. Genetics and Molecular Research 11(3): 2855-2861

El-Beltagi H S, Ahmed O K \& El-Desouky W (2011). Effect of low doses $\gamma$-irradiation on oxidative stress and secondary metabolites production of rosemary (Rosmarinus officinalis L.) callus culture. Radiation Physics and Chemistry 80(9): 968-976

Fakhri Y, Khaneghah A M, Conti G O, Ferrante M, Khezri A, Darvishi A, Ahmadi M, Hasanzadeh V, Rahimizadeh A \& Keramati H (2018). Probabilistic risk assessment (Monte Carlo simulation method) of $\mathrm{Pb}$ and $\mathrm{Cd}$ in the onion bulb (Allium cepa) and soil of Iran. Environmental Science and Pollution Research 25(31): 30894-30906

FAO (2017). Food and Agriculture Organization Statistical Database. Retrieved February 27, 2017

Farajpour M, Ebrahimi M, Baghizadeh A \& Aalifar M (2017). Phytochemical and yield variation among Iranian Achillea millefolium Accessions. HortScience 52(6): 827-830

Fernandes Â, Barreira J C, Antonio A L, Oliveira M B P, Martins A \& Ferreira I C (2016). Extended use of gamma irradiation in wild mushrooms conservation: validation of $2 \mathrm{kGy}$ dose to preserve their chemical characteristics. LWT-Food Science and Technology 67: 99-105

Frazier M J, Kleinkopf G E, Brey R R \& Olsen N L (2006). Potato sprout inhibition and tuber quality after treatment with highenergy ionizing radiation. American Journal of Potato Research 83(1): 31

Gardiner M G \& Cleland R (1974). Peroxidase changes during the cessation of elongation in Pisum sativum stems. Phytochemistry;(United States) 13(7): 1095-1098

Hamamouch N \& Adil E (2019). The role of the Shikimate and the Phenylpropanoid Pathways in root-knot nematode Infection. 81: 307-321

Hassanabadi M, Ebrahimi M, Farajpour M \& Dejahang A (2019). Variation in essential oil components among Iranian Ferula assafoetida L. accessions. Industrial Crops and Products 140: 11598

He Q \& Luo Y (2007). Enzymatic browning and its control in fresh-cut produce. Stewart Postharvest Review 3(6): 1-7

Hong M, Yoon Y, Kim D, Kim S, Kang S, Kim D, Seo Y \& Kim J (2018). Phenotypic and molecular responses of wheat (Triticum aestivum L.) to chronic gamma irradiation. Journal of Agricultural Science and Technology 20(1): 167-178

Jeong R-D, Chu E-H, Lee G W, Cho C \& Park H-J (2016). Inhibitory effect of gamma irradiation and its application for control of postharvest green mold decay of Satsuma mandarins. International Journal of Food Microbiology 234: 1-8

Jeong R D, Jeong M A \& Park M R (2017). Gamma irradiation induced disease resistance of pear (Pyrus pyrifolia "Niitaka") against Penicillium expansum. Journal of Phytopathology 165(9): 626-633

Jones H A \& Mann L K (1964). Onions and their allies. Soil Science 98(1): 68

Kader A A (1986). Potential applications of ionizing radiation in postharvest handling of fresh fruits and vegetables. Food Technol 40(6): $117-121$

Khan Q U, Mohammadzai I, Shah Z, Khattak T N, Noreen H \& Hassan W (2018). Effect of Gamma Irradiation on Nutrients and Shelf Life of Peach (Prunus persica L.) Stored at Ambient Temperature. The Open Conference Proceedings Journal 9(1): 8-15

Lee H, Kim J, Baek M, Yoo J \& Kwon S (2003). Effects of low dose gamma irradiation on physiological activities of radish (Raphanus sativus) during early growth and reduction of ultraviolet-B stress. Journal of the Korean Society for Horticultural Science 44: 314-320 
Ling A P K, Chia J Y, Hussein S \& Harun A R (2008). Physiological responses of Citrus sinensis to gamma irradiation. World Applied Sciences Journal 5(1): 12-19

Livak K J \& Schmittgen T D (2001). Analysis of relative gene expression data using real-time quantitative PCR and the $2-\Delta \Delta C T$ method. Methods 25(4): 402-408

MacAdam J W, Nelson C J \& Sharp R E (1992). Peroxidase activity in the leaf elongation zone of tall fescue: I. Spatial distribution of ionically bound peroxidase activity in genotypes differing in length of the elongation zone. Plant Physiology 99(3): 872-878

Mai F \& Glomb M A (2013). Isolation of phenolic compounds from iceberg lettuce and impact on enzymatic browning. Journal of Agricultural and Food Chemistry 61(11): 2868-2874

Moussa H (2011). Low dose of gamma irradiation enhanced drought tolerance in soybean. Acta Agronomica Hungarica 59(1): 1-12

Moussa H R (2008). Gamma irradiation effects on antioxidant enzymes and G6PDH activities in Vicia faba plants. Journal of New Seeds 9(1): 89-99

Nissen P (1985). Dose responses of auxins. Physiologia Plantarum, 65(4): 357-374

Nouri J \& Toofanian F (2001). Extension of storage of onions and potatoes by gamma irradiation. Pakistan Journal Bioloqical Sciences 4(10): 1275-1278

Pereira E, Barros L, Dueñas M, Antonio A L, Santos-Buelga C \& Ferreira I C (2015). Gamma irradiation improves the extractability of phenolic compounds in Ginkgo biloba L. Industrial Crops and Products 74: 144-149

Pereira E, Pimenta A I, Calhelha R C, Antonio A L, Verde S C, Barros L, Santos-Buelga C \& Ferreira I C (2016). Effects of gamma irradiation on cytotoxicity and phenolic compounds of Thymus vulgaris L. and Mentha x piperita L. LWT-Food Science and Technology 71: 370-377

Rutherford P \& Whittle R (1984). Methods of predicting the long-term storage of onions. Journal of Horticultural Science 59(4): 537-543

Sabiu S, Madende M, Ajao A A-n, Aladodo R A, Nurain I O \& Ahmad J B (2019). The Genus Allium (Amaryllidaceae: Alloideae): Features, Phytoconstituents, and Mechanisms of Antidiabetic Potential of Allium cepa and Allium sativum Bioactive Food as Dietary Interventions for Diabetes, Elsevier, pp. 137-154

Steel R G \& Torrie J H (1980). Principles and procedures of statistics, a biometrical approach. McGraw-Hill Kogakusha, Ltd.,

Steele J H (2000). Food irradiation: a public health opportunity. International Journal of Infectious Diseases 4(2): 62-66

Tripathi J \& Variyar P (2016). Gamma irradiation inhibits browning in ready-to-cook (RTC) ash gourd (Benincasa hispida) during storage. Innovative Food Science \& Emerging Technologies 33: 260-267

Wang J, Jiang J, Wang J, Wang Z, Yang X \& Jia L (2019). The influence of gamma irradiation on the storage quality of bamboo shoots. Radiation Physics and Chemistry 159: 124-130

Wang X, Ma R, Cao Q, Shan Z \& Jiao Z (2018). Enhanced tolerance to salt stress in highland barley seedlings (Hordeum vulgare ssp. vulgare) by gamma irradiation pretreatment. Acta Physiologiae Plantarum 40(9): 174

Wickens T D \& Keppel G (2004). Design and analysis: A researcher's handbook. Pearson Prentice-Hall

Xia J \& Wishart D S (2016). Using MetaboAnalyst 3.0 for comprehensive metabolomics data analysis. Current Protocols in Bioinformatics 55(1): 14.10.1-14.10.91

Zarbakhsh S \& Rastegar S (2019). Influence of postharvest gamma irradiation on the antioxidant system, microbial and shelf life quality of three cultivars of date fruits (Phoenix dactylifera L.). Scientia Horticulturae 247: 275-286 